\title{
New measurements of phytoplankton aggregation in a flocculator using videography and image analysis
}

\author{
Anya Waite ${ }^{1, *}$, Scott Gallager ${ }^{1}$, Hans G. Dam ${ }^{2}$

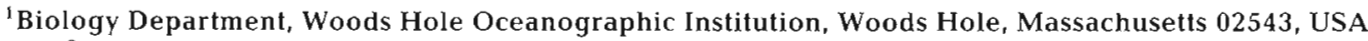 \\ ${ }^{2}$ Department of Marine Sciences, University of Connecticut, Groton, Connecticut 06340, USA
}

\begin{abstract}
Diatom aggregation can increase the sedimentation rate of the intense pulses of carbon formed during diatom blooms. Laboratory studies of aggregation dynamics have been troubled by the unavoldable disruption of aggregates in laboratory flocculators due to subsampling and electronic particle counting. Aggregate disruption prevents accurate measurement of aggregation rate and makes observation of particle structure impossible. This led us to develop a new non-disruptive method to quantify diatom aggregation using high-resolution video and image analysis. The system easily resolved cells of Chaetoceros neogracile 6 to $8 \mu \mathrm{m}$ n diameter, and facilitated observations of aggregate morphology. C. neogracile made either ball-like or net-like aggregates dependmg on culture density and physiological state. Only the net-like aggregates reached a substantial size (>1 mm). A Silimited batch culture experiment indicated that stickiness of C. neogracile increased significantly with increasing severity of nutrient limitation. Thus increase was not detectable by the subsampling and electronic particle counting method. It is likely that spine formation, cell-surface bound sugars, and transparent exopolymer particles all played a role in determinung aggregate structure and changes in stickiness. The stickiness calculation model assumes cultures are initially suspensions of single cells which form doublets as they aggregate. This assumption was tested by comparing mean particle size in a culture with the percentage of cells in aggregates as determined using nearest neighbor distances, allowing us to assess the mean number of cells per aggregate. C. neogracile commonly formed aggregates contaning anywhere between 2 and 10 cells showing that model assumptions can be violated under normal experimental conditions. A larger field of view was necessary to estimate the larger particle sizes typical of coastal diatom blooms.
\end{abstract}

KEY WORDS: Aggregation Adhesion - Video Image analysis Diatom Chaetoceros neogracile

\section{INTRODUCTION}

Coastal diatom blooms produce some of the highest annual pulses of 'new' production found in the global ocean (Burrell 1988). These blooms can be of very short duration, sometimes peaking over the period of a single week (Laws et al. 1988). Rapid removal of this sudden accumulation of biomass can be effected by the formation of cell aggregates whose maximum sedimentation rates are orders of magnitude higher than

\footnotetext{
- Present address: Centre for Water Research, Dept of Environmental Engineering, Univ of Western. Australia, Nedlands, Western Australia 6907, Australia.

E-mail:waite@cwr.uwa.edu.au
}

those of single cells (Jackson 1990, Riebesell 1991). This process can terminate a bloom before nutrients are fully depleted at the surface (Jackson \& Lochmann 1993). Aggregation also changes the availability of food to grazers (Stoecker et al. 1981, Hart 1991), especially those with size-preferences for their prey (Rubenstein \& Koehl 1977, Shimeta \& Jumars 1991). The dynamics of aggregation are thus of central importance to the fate of diatom carbon in coastal ecosystems.

Typically, aggregation rates are quantified by observing phytoplankton cultures or field samples in a cylindrical device known from the sanitary engineering literature as a flocculator This device generates a known laminar shear, and thus a known number of 
particle collisions per unit time for a given cell diameter and density (van Duuren 1968, Drapeau et al. 1994). The collision and attachment of cells in the flocculator results in changes in particle size distribution, which are quantified by regularly subsampling the spinning flocculator over short periods of time $(<1 \mathrm{~h})$. From these data, we can quantify important aspects of aggregation such as the probability of attachment between cells (stickiness, or $\alpha$ ) (Dam et al. 1995).

Our preliminary experiments and the experience of colleagues ( $T$. Kiorboe pers. comm.) indicate that subsampling and electronic particle counting submit suspensions to high shear which disrupts aggregates. In one extreme case, we created visible centimeter-sized aggregates within the flocculator using Chaetoceros neogracile cells with long spines, but found no measurable difference in the size spectrum of particles measured by the particle counter after subsampling. Though commonly recognized, this disruption has been difficult to quantify because there was until now no direct method of measuring aggregate size within the flocculator without removing a water sample, and potentially breaking up aggregates. Such disruption is also difficult to predict because it is likely to be highly variable and species specific. Cultures forming tight aggregates may be less susceptible to disruption than species forming loose aggregates, for example (Stratford 1992). Disruption would in general result in. underestimates of stickiness. While previously published measurements may be internally consistent, the aforementioned problem indicates that the accuracy of aggregation measurements is potentially in doubt. Other methods of measuring stickiness have been attempted, but they involve either manual quantification of individual aggregates (Alldredge \& McGillivary 1991), adhesion to artificial surfaces like glass (Straley \& Bruce 1979) or glass beads (Kiorboe \& Hansen 1993).

Over the last 5 yr the use of video has revolutionized the study of suspended plankton populations in the ocean by allowing non-invasive observation using optical sampling (Davis et al. 1992, Gallager et al. $1994,1996)$. Using the same principle, we fitted a video analysis system to a modified flocculator Quantitative videography allows us to measure particle size and number, non-disruptively, for a wide range of particle sizes and shapes. This method also increases the possible resolution of aggregate measurements, and yields images of the actual particles from which we can observe aggregate shape and porosity. In this paper we compare new video measurements of diatom stickiness with previously used methods in a series of flocculation experiments with the diatom species Chaetoceros neogracile, and briefly discuss the results of initial field tests of the instrument. We show that the method is simple and yields a new and useful set of measurements critical in the study of diatom aggregation.

\section{METHODS}

Experimental setup. To estimate aggregation more accurately, we built a video system to non-invasively record changes in cell size distributions within an experimental Couette chamber (flocculator) The flocculator consists of 2 concentric Plexiglas cylinders. The volume between the cylinders is filled with either a field sample or a laboratory culture, and the outer cylinder is rotated to generate a laminar shear within the volume, causing cells to collide and adhere into aggregates if sticky. We used the modified version of the flocculator described by Drapeau et al. (1994), who placed the rotating chamber horizontally rather than vertically, reducing the effect of gravity on differential settlement of particles during operation (Fig. 1). To assess aggregation, we used a high-resolution imaging system and video recorder to observe aggregate formation as it occurred within the flocculator A Pulnix TM-7EX CCD camera fitted with a Zeiss $20 \times$ longworking distance objective lens [working distance: $1.2 \mathrm{~cm}$, depth of field: $0.2 \mathrm{~mm}$, NA (numerical aperture of objective): 0.4] was focused within the laminar shear zone of the Couette chamber The beam from a fiberoptic light source was directed througth the water bath, the Couette chamber and into the camera. The camera's electronic shutter was set to provide a $1 / 10000 \mathrm{~s}$ exposure time for each video field to eliminate blurring

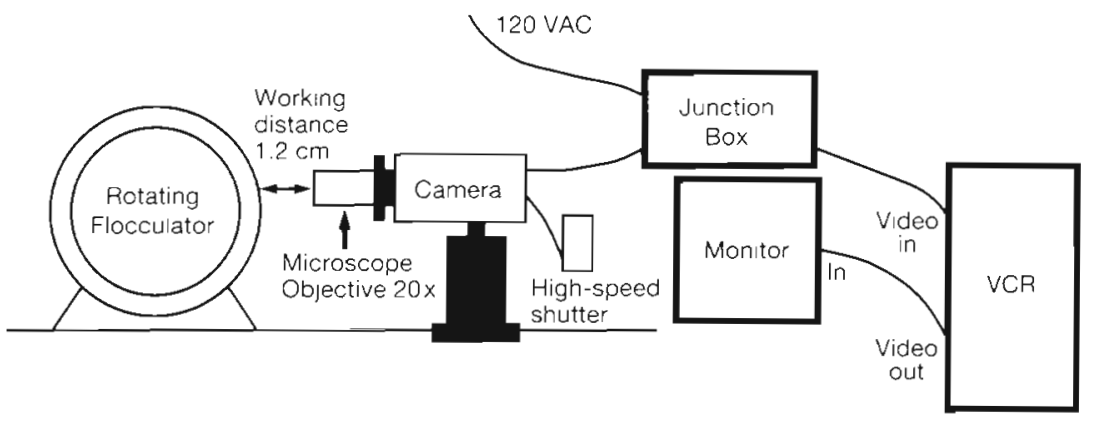

Fig. 1 Video setup for aggregate size measurement. A CCD camera fitted with a $20 \times$ microscope objective is placed such that it is focussed on the volume within the flocculator. A high-speed shutter $(1 / 10000)$ stops movement as the flocculator spins, allowing individual video images to be used for cell and aggregate size analysis. See text for deta.ls 
of the video image while the flocculator was operating. The system produced high-contrast bright-field exposures at 60 images per second which were recorded on a Sony EVO-9600 series Hi8 recorder. We used 2 fields of view (FOV): a small FOV with dimensions ca $800 \mu \mathrm{m}$ (width) $\times 400 \mu \mathrm{m}$ (height) $\times 20 \mu \mathrm{m}$ resulting in an imaged volume of $0.0064 \mu \mathrm{l}$, and a large FOV with dimensions of $14 \mathrm{~mm}$ (width) $\times 10 \mathrm{~mm}$ (height) resulting in an imaged volume of ca $3 \mathrm{ml}$. The Chaetoceros neogracile experiments were conducted with the small FOV configuration

Digital image processing was used to calculate statistical parameters associated with the aggregation process. One in every 60 images was selected by the image processor for analysis (yielding a temporal resolution of $1 \mathrm{~s}$ ). The number of images chosen for analysis per unit time represented a compromise between maximizing temporal resolution of the resulting data, and completing the automatic size analyses in a reasonable amount of time. Analyzing 1 in every 60 images allowed the system to analyze $45 \mathrm{~min}$ of video data in $8 \mathrm{~h}$, which was acceptable for our purposes.

All image processing was done within Bioscan's Optimas software package. For each video field, the image was captured, individual cells isolated using thresholding and edge detection (Fig. 2A), and the cross-sectional area of each cell in the field of view was calculated. For simple, ball-shaped aggregates (Fig. 2A) such analysis was straightforward. However for net-like aggregates (Fig. 2B) where porosity was high, each particle became isolated in analysis, yielding, instead of an aggregated measurement, a series of single cells. We observed that, even in large porous aggregates, cells of Chaetoceros neogracile in aggregates were not more than $30 \mu \mathrm{m}$ apart in cross-section. For this reason we measured nearest neighbor distance (NND) for each individual cell, and assumed that cells with a NND below a threshold of $30 \mu \mathrm{m}$ were part of an aggregate. We developed a method to determine which cells were part of a single aggregate essentially by expanding a halo $30 \mu \mathrm{m}$ from the centre of each cell, through a series of erosions and dilations (Fig. 2D). Cell spines of $C$. neogracile were approximately this length, as shown in the electron micrographs (Fig. 3), and we considered the spines one of the likely factors causing spaces to form between the cells. We thus included all cells within $30 \mu \mathrm{m}$ of each other into a single aggregate in which the halos became contiguous (Fig. 2D), but then shrank the halo back around the individual cells so that the cross-sectional areas of all cells in the aggregate would be binned into a single size measurement (Fig. 2E). These manipulations were done automatically for each video field, allowing us to measure the volume of the cells contained within netlike aggregates.
The size data from each video field, once generated, were then binned into groups of 50 consecutive images. The mean size of each bin was then taken as a single data point. Each data point shown in the figures below thus represents mean size of all the cells in 50 images, in a total of about $0.32 \mu \mathrm{l}$ of culture medium sampled over $50 \mathrm{~s}$ of the experiment. The cell size measurements we made were calibrated by adding $10 \mu \mathrm{m}$ polystyrene beads into the solution within the flocculator. and measuring a size distribution of $10 \mu \mathrm{m}$ particles.

Calculations. Initially we assume a spherical cell, in order to gain a particle diameter measurement from a cross-sectional area, with particle diameter (d) which was calculated simply as $d=2(X / \pi)^{1 / 2}$ where $X=$ crosssectional area. For the initial testing of the method, all size data were calculated as equivalent spherical diameter (see above), which is acceptable if we accept the assumption that cells are randomly oriented in the flow (Morel \& Bricaud 1986) and that a cross-sectional area of a cell roughly represents the cross-section of a sphere.

The stickiness calculations of Kiørboe et al. (1990) depend on the increase in mean particle size over time as cells collide and adhere to each other within the flocculator:

$$
\alpha=\left\{m \cdot \pi \cdot \exp \left(s^{2} / d^{2}\right)\right\} /(7.824 \cdot V \cdot S)
$$

where $\alpha$ is stickiness, $m=$ slope of in particle diameter $(\mu \mathrm{m})$ vs time $(\mathrm{s}), s^{2}=$ variance in the size distribution of the particles $(\mu \mathrm{m})$ at $t=0, \mathrm{~d}=$ mean particle diameter $(\mu \mathrm{m}), V=$ the volume fraction of particles at $t=$ 0 (ppm), and $S=$ mean shear rate $\left(\mathrm{s}^{-1}\right)$. This simplification is based on the assumption that increase in mean particle size is caused only by the collision and adhesion of single cells, forming doublets (Kiørboe et al. 1990). We can test this assumption, implicit in all previous work, in our experiments using the video method and 2 simple calculations. The distribution of NNDs within a culture gives us an estimate of the number of cells packaged in aggregates. We can then compare the mean cell size in an experiment with one we would expect if all aggregates were doublets, and confine our analysis to parts of the experiment (most likely the initial stages) where this assumption holds. If only doublets are being formed in a given experiment, and we assume all cells are the same diameter then:

each cell diameter $=1 ; a=$ number of single cells; $b=$ number of doublets; $M=$ mean particle diameter (in no. of cell diameters); $N=$ total number of cells.

Assume no surface area conservation, since we are dealing in the initial case with porous aggregates where cell surfaces do not touch. 


$$
M=(a+2 b) /(a+b)
$$

Conservation of particle number is neinssary, so

$$
N=a+2 b
$$

where $N$ is assumed to be a constant for a given experiment. Combining these 2 equations, we then get

$$
M=N /(N-b)
$$

where $N$ and $b$ are known or measurable, so we can solve for $M$.

If only doublets are formed, $b$ must be equal to the number of cells in aggregates (defined here as cells with NNDs $<30 \mu \mathrm{m}$ ). We calculated the frequency distribution of the nearest-neighbor distances (NNDs) at 1 min intervals, binned the NNDs into size categories and calculated the \% cells within aggregates at any time during the experiment.

For example, in Expt 12/16a (see below) mean particle diameter increased by $8 \%$ in about 40 min. If the $8 \%$ size increase was caused solely by singlets forming doublets, $14.9 \%$ of cells would have to be in aggregates to account for the observed particle size increase $(b=0.149 \mathrm{~N})$. However, if all aggregates formed were 10 cells per aggregate, only $8.2 \%$ of cells would need to be aggregated to cause the same increase in mean size. In Fig. 4 we show theoretical increases in percentage aggregated cells as a function of mean particle size, for cases where aggregates are formed only as doublets, triplets, quadruplets, or groups of 10 . If we isolate stickiness calculations to cases whose size and NND distribution fall below the doublet line of the Fig. 4 as shown, we can be confident that the assumptions behind the stickiness calculation are met.

All stickiness calculations were made using the slope from regressions of $\ln$ (cell diameter, $\mu \mathrm{m}$ ) versus time ( $\mathrm{s}$ ). The slope of the regression was plugged into the above equation for $\alpha$. We have indicated the statistical strength of the regression coefficient ( $a s \mathrm{R}^{2}$ ) from each experiment.

Experimental design. Duplicate 121 batch cultures ( $\mathrm{a}$ and $\mathrm{b}$ ) of the marine diatom Chaetoceros neogracile were inoculated into in $\mathrm{F} / 2$ medium and grown on a 14:10 h day:night cycle at $100 \mu \mathrm{mol}$ photons $\mathrm{m}^{-2} \mathrm{~s}^{-1}$. Day 0 of the experiment was on December 4 (hereafter referred to as $12 / 4$ ), when cells were in early logarithmic growth. Initial nutrient concentrations were such that when growth slowed (between $12 / 10$ and 12/12), silica was limiting in the medium (See Waite et al. 1995 for more detail) The experiment was terminated on 12/16, about 4 d into stationary phase. Every second day, 1 l of each culture was taken for stickiness measurements, placed in a rotating Couette chamber at a mean shear of $5 \mathrm{~s}^{-1}$ and exposed to this shear continuously for $2 \mathrm{~h}$. Video measurements were made continuously for the first $45 \mathrm{~min}$ of each experiment. At 0,15 , $30,45,60$, and $120 \mathrm{~min}$ after the beginning of each
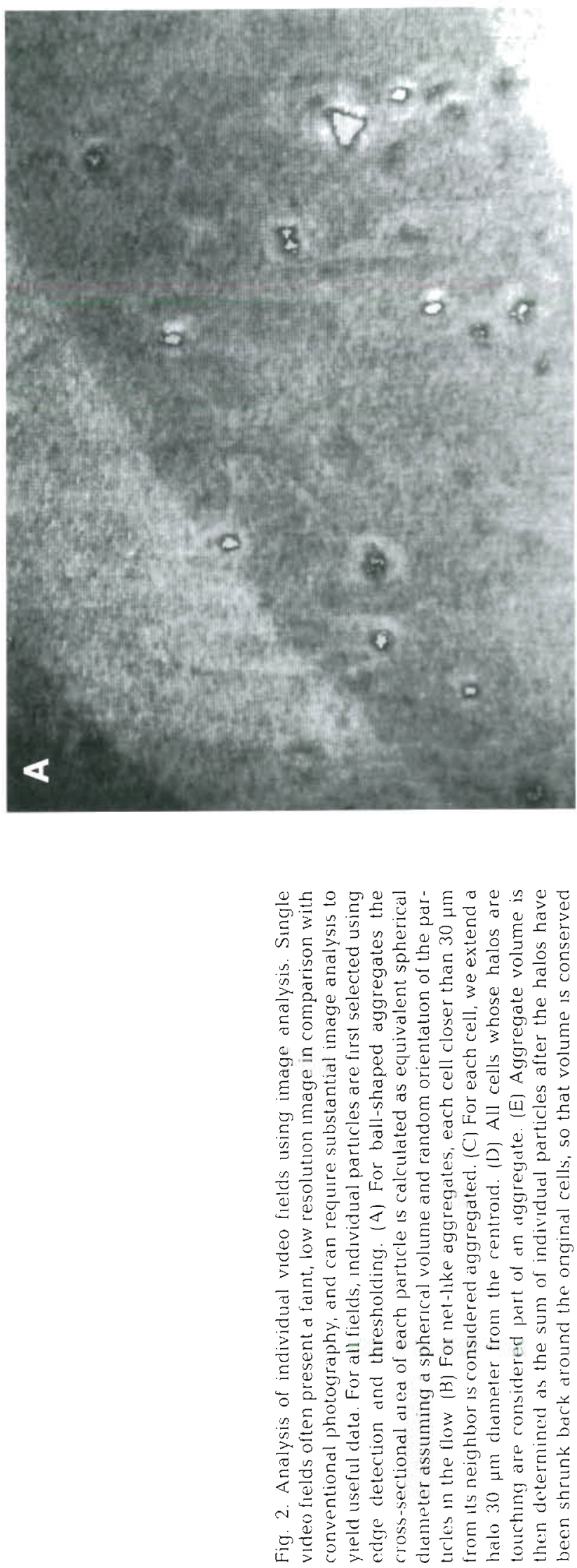

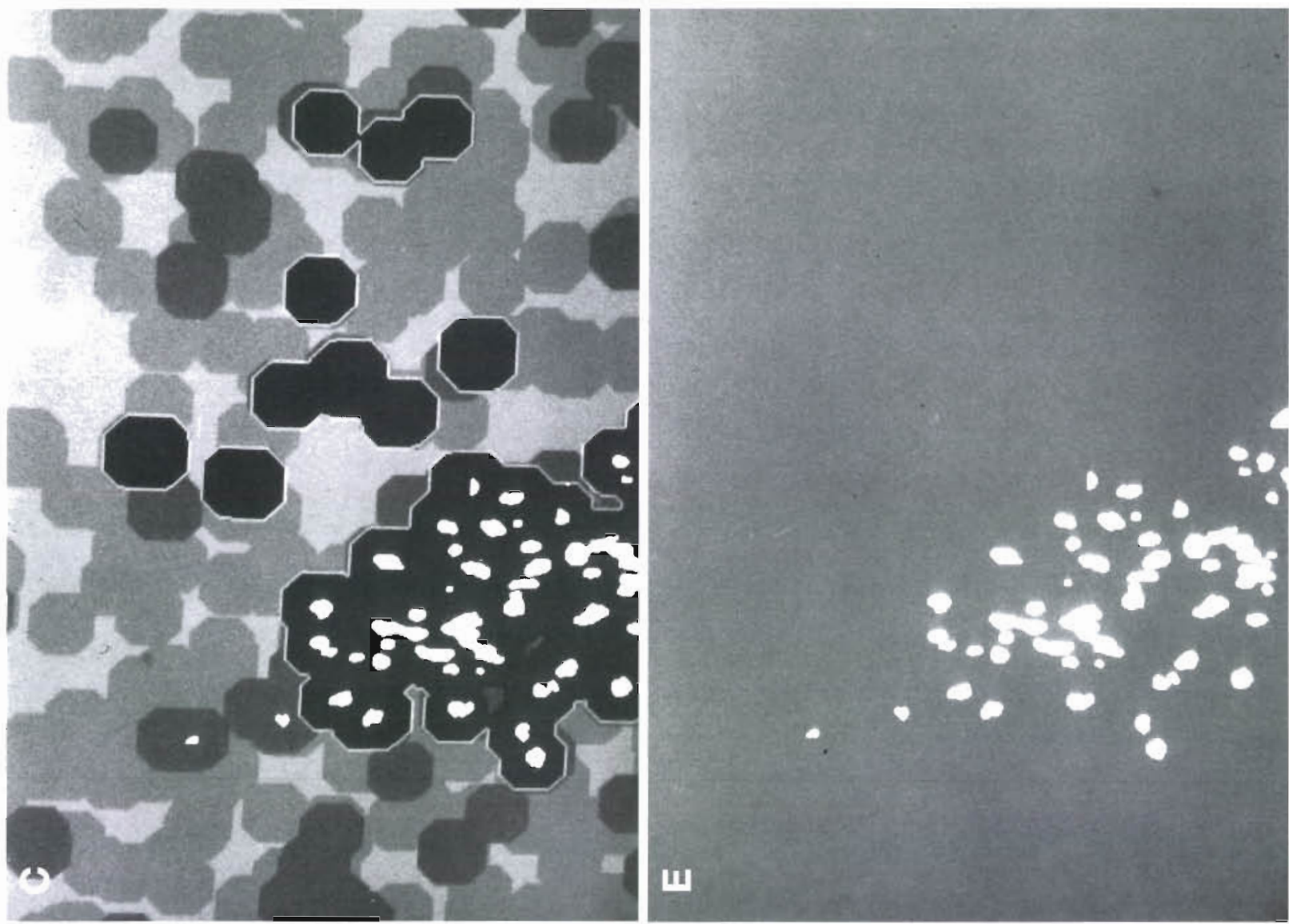

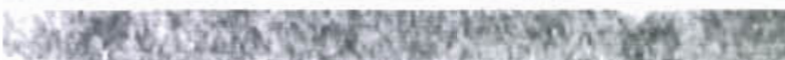

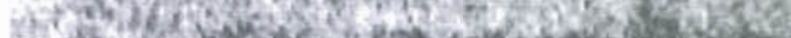

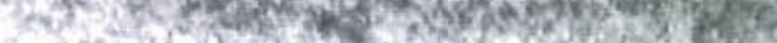

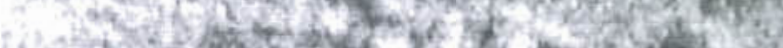

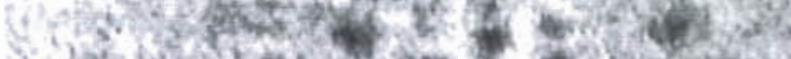
20 he haty

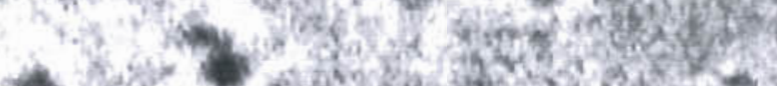

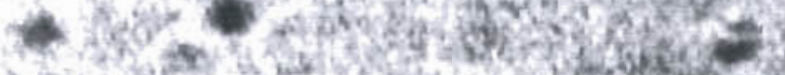

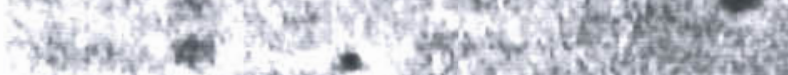

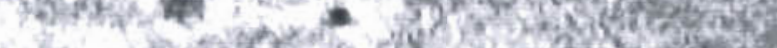

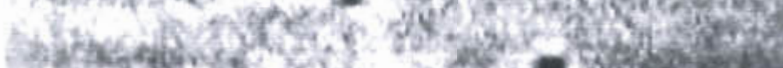

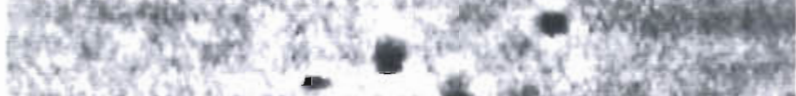

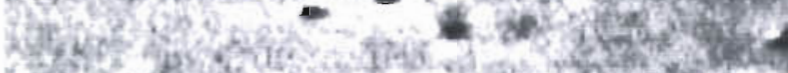
5. $=25$.

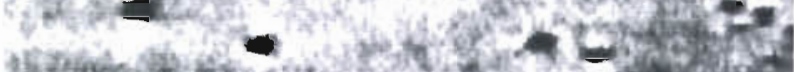

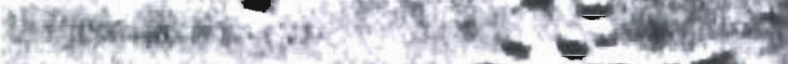

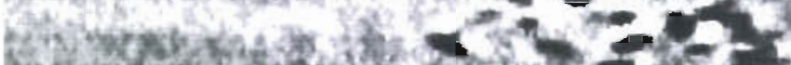

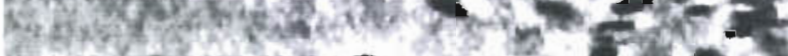

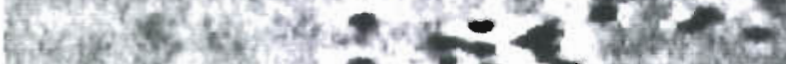

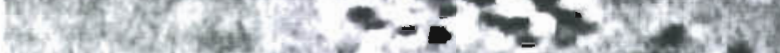
W

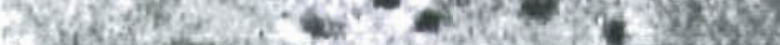

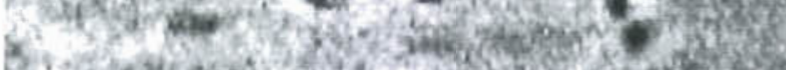

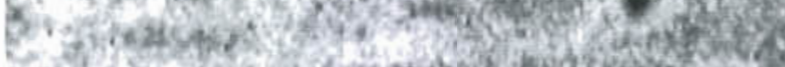

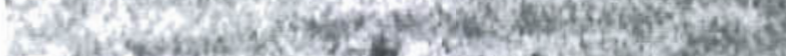

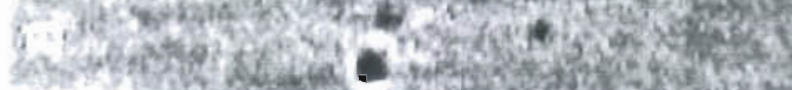

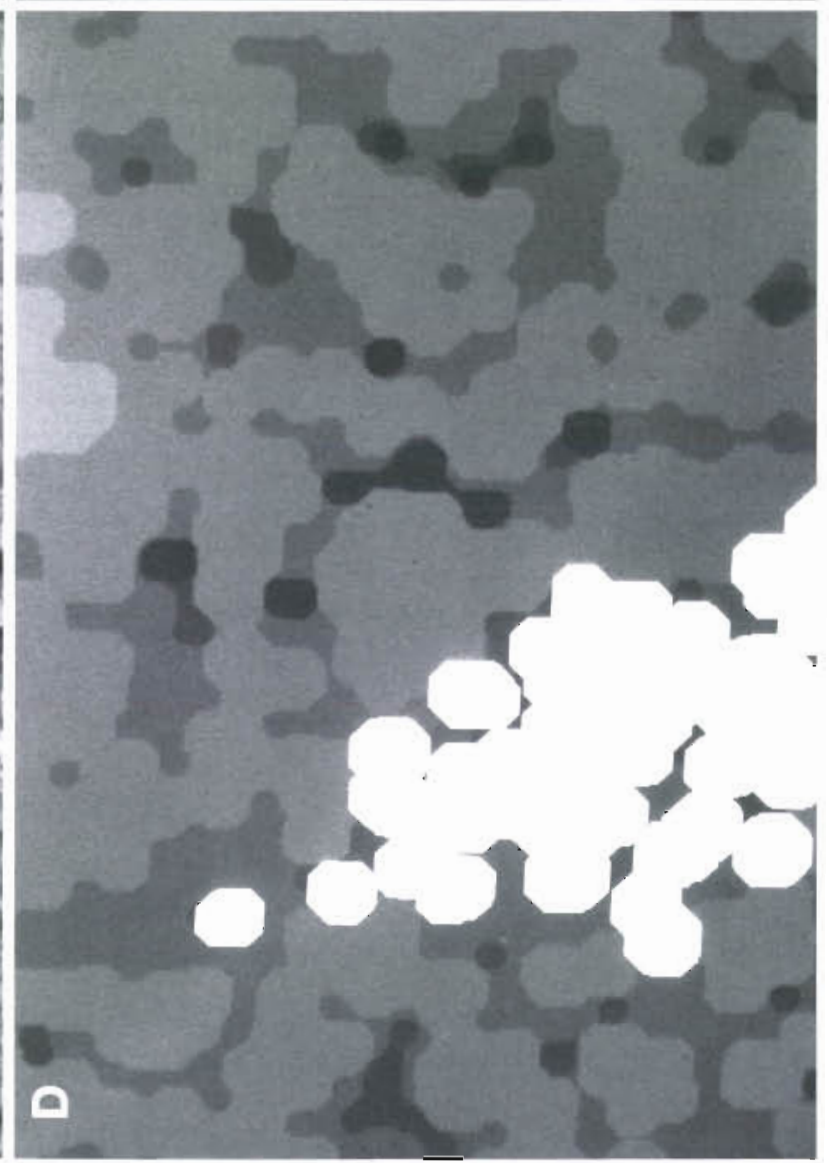



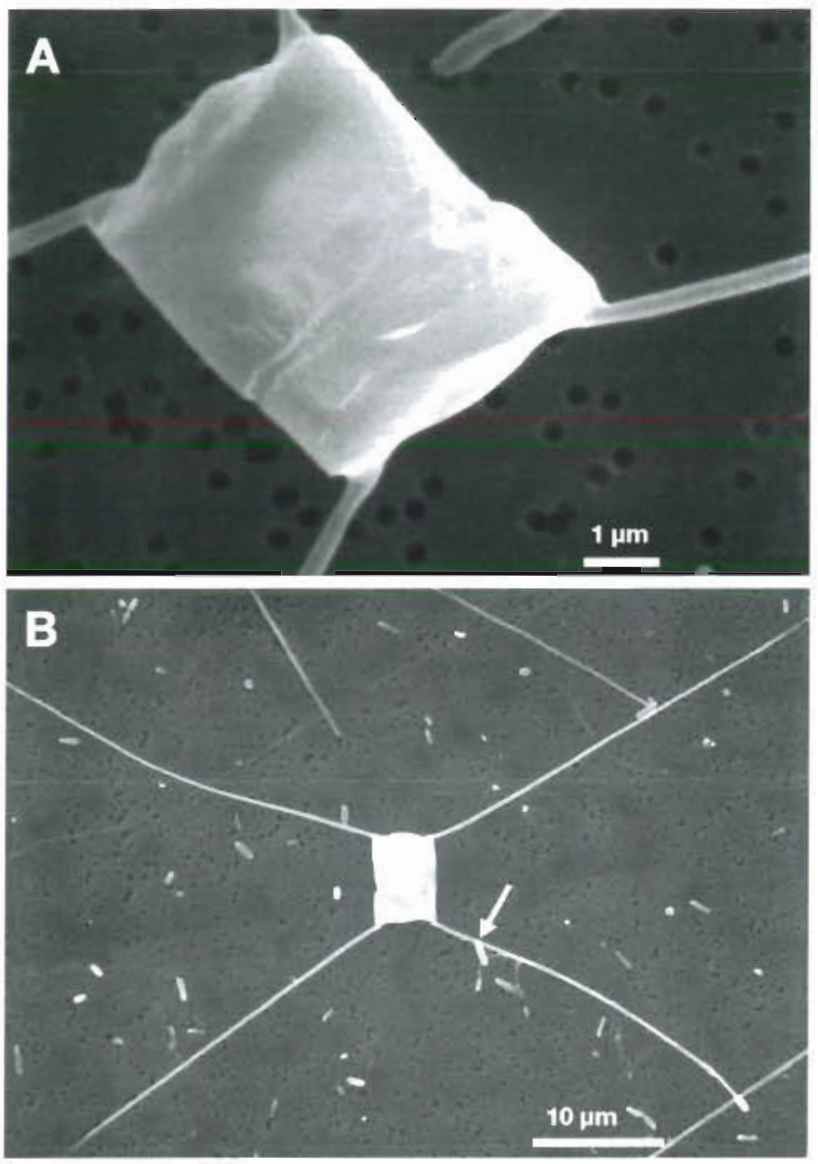

Fig. 3. Chaetoceros neogracle. Electron micrographs of cells from the cultures used in aggregation experiments. (A) Close-up of frustule. Note absence of bacteria on cell surface. (B) Entire cell with spmes extending $c d 30 \mu \mathrm{m}$ from the frustule. A bacterium (arrow) is attached to a cell spine. Cultures were growing at $>1 \mathrm{~d}^{-1}$, and were sampled in midlog phase. Though bacteria were present in the: cultures at all times, they did not commonly colonize the cells

experiment, water samples were taken from the rotating Couette chamber using a metal sampling port (Drapeau et al. 1994) and size distribution within the chamber was measured using an Elzone Particle Counter to compare with video measurements

Field measurements. Preliminary field tests of the video-flocculator system were run in Friday Harbor, Washington State, USA, as part of the SIGMA research initiative (Kiørboe et al. 1996). Daily videographic measurements using the video-flocculator were made on field populations sampled from East Sound, Orcas Island, as part of aggregation experiments.

\section{RESULTS AND DISCUSSION}

In our experiment, the cultures of Chaetoceros neogracile grew rapidly in logarithmic growth beginning

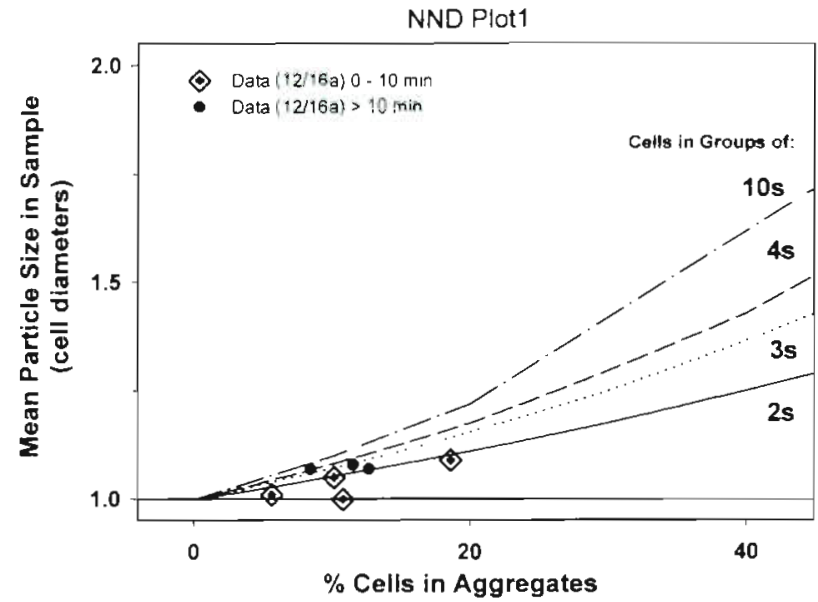

Fig. 4. Curves showing theoretical relationship between $\%$ cells in aggregates and mean particle size in culture for cases in which cells aggregate to form exclusively doublets (2s), triplets (3s), quadruplets (4s) or groups of 10 (10s). To comply with the assumptions inherent in the stickiness calculation, points should fall below the doublet line. Data from Expt $12 / 16$ a are superimposed. Note that early in the experiment ( 0 to $10 \mathrm{~min}$ ), data suggest doublets are being formed. Later in the experiment, data fall above the line suggesting groups of 3 to 10 are being formed

on Day $0(12 / 4)$, and continued until growth became limited by the availability of silicate in the medium between Days 6 and 8 (12/10 to 12/12). Image analysis of parficle size distribution during flocculator experiments executed every second day yielded particle size data of very high temporal resolution (Fig. 5) allowing us to calculate $\alpha$ from the slope of the size versus time relationships (Table 1 ). Generally the increase in mean size was only $2 \mu \mathrm{m}$ over 45 min of exposure to a shear of $5 \mathrm{~s}^{-1}$ within the flocculator (Fig. 5), so actual values of $\alpha$ were low (ca 0.01; Table 1). However, the high sampling frequency of the new video method yielded a high statistical confidence that these small size increases were real, with highly significant $p$ values below 0.0001 (Table 1) Comparing calculated values of a using videography with those using electronic particle counting indicated that the videography was superior in both sampling frequency (and hence statistical confidence slope estimate) and consistency of data. In addition, there were several new features of the behavior of cells within the flocculator which emerged from our study (see below).

There are several special considerations when making photographic measurements of particle size. Especially if aggregates are porous, it is important to consider the difference between the volume of cells making up the aggregate and the total aggregate volume itself when making size calculations (Jackson et al. 1995) To make an accurate estimate of the stickiness coefficient $\alpha$ which represents the probability 

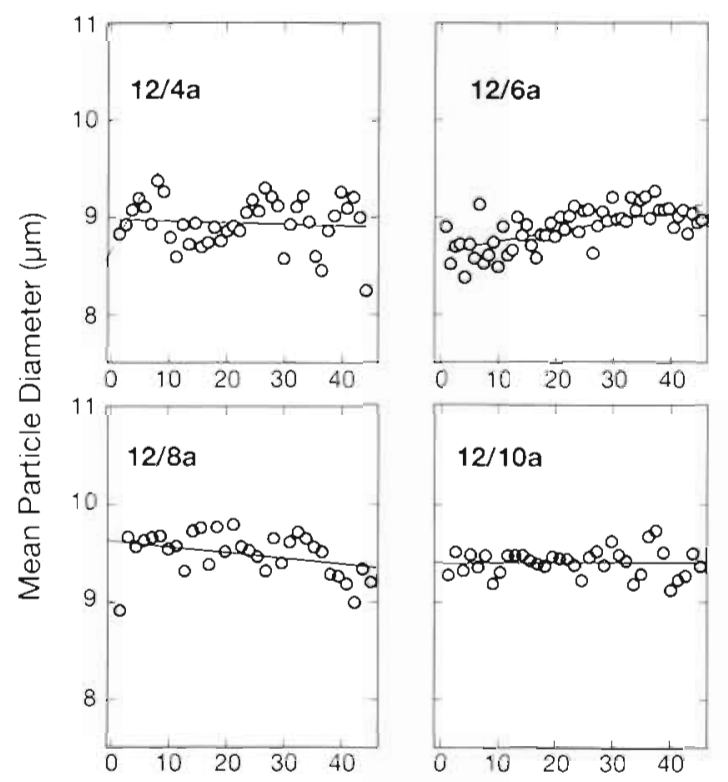

Fig. 5. Chaetoceros neogracle. Particle diameter vs time plots for individual aggregation experiments on cultures grown in batch cultures over $12 \mathrm{~d}$. Equivalent spherical diameter is calculated as cross-sectional area using image analysis from high-resolution video recordings of phytoplankton cultures (see text for details). Solid lines are significant linear regressions (order 1) of diameter vs time over 45 min. Slopes shown as dashed lines are significant regressions of diameter vs time over the first $10 \mathrm{~min}$ of the experiment. Note bimodal curves in later experiments. In all graphs, ' $a$ ' and ' $b$ ' each designate one of the 2 replicate 12 I cultures
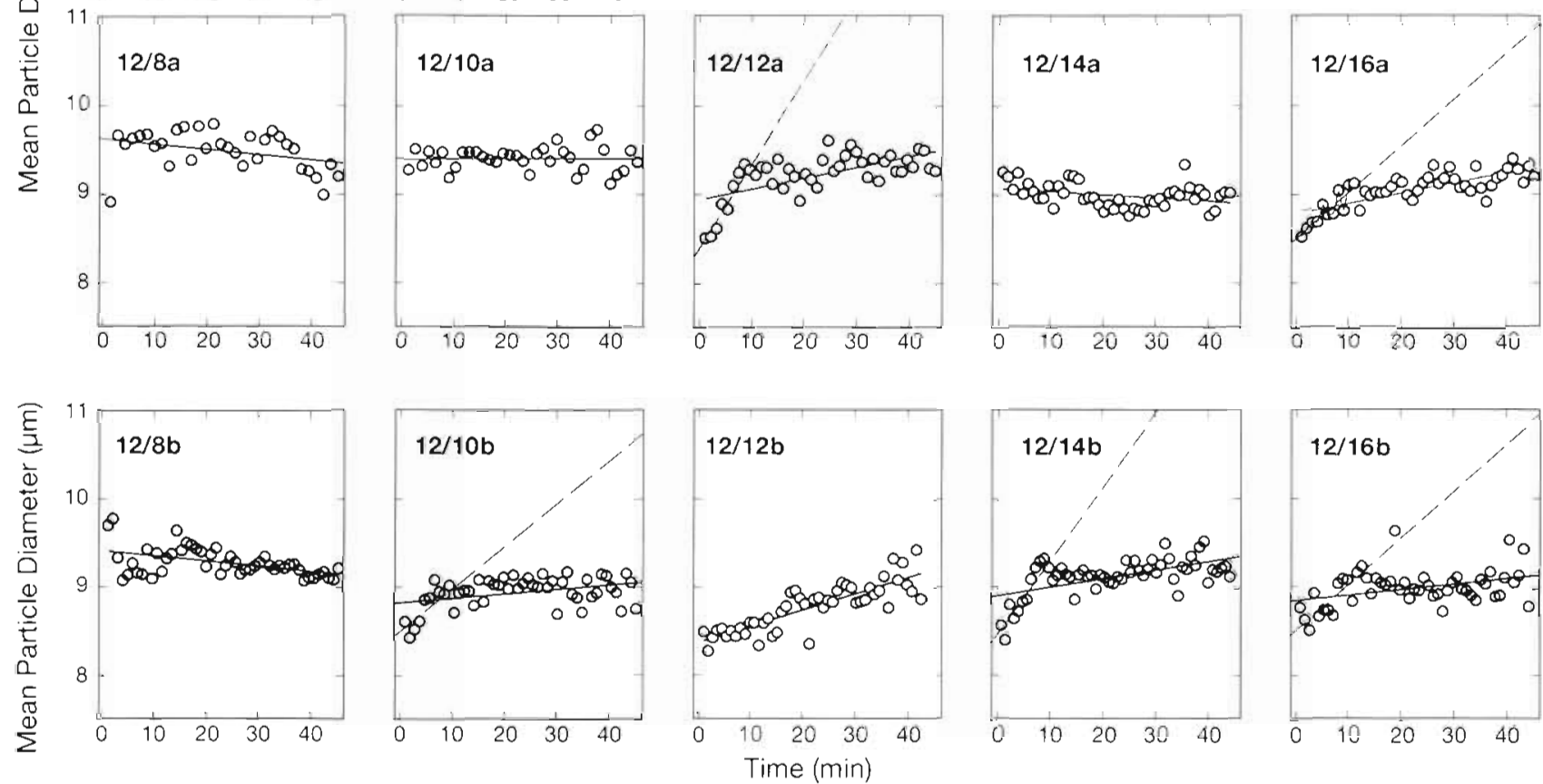

that 2 colliding cells will adhere, we are initially not concerned with the larger issues of fractal dimension or porosity of the resulting aggregates. If possible we Lochmann 1993), the short initial period when particle sizes are small and shapes are simple probably represents the most accurate estimate of $\alpha$ (O'Melia \& Tiller wish to work with volume-conserved measurements of singlet cells forming doublets. One strength of videography in this regard is that we can actually resolve the singlets and doublets we are interested in, and need not average over a larger aggregate volume for $\alpha$ calculations

Though most experiments started with a mean particle diameter in the culture of $8 \mu \mathrm{m}$, some seemed to have a larger initial mean particle diameter (9 to $10 \mu \mathrm{m}$ ), suggesting cells were aggregated before the experiment started. In our study, data from $12 / 8$ (culture a) and $12 / 14$ (culture a) might be questionable for this reason.

Because of the assumption of constant volume fraction in alpha calculations (Kiørboe et al. 1990, Jackson \&

Table 1. Estimates of stickiness coefficient, $\alpha$, compared between the 2 methods, (1) subsampling and electronic particle counting, and (2) high-resolution videography. All estimates are calculated using measurements from the same duplicate cultures of Chaetoceros neogracile. Over time in batch culture, growth rate slowed due to Si limitation. Numbers in bold indicate significant positive estimates of stickiness in the video measurements

\begin{tabular}{|c|c|c|c|c|c|c|c|c|}
\hline \multirow[t]{2}{*}{ Date } & \multicolumn{2}{|c|}{$\begin{array}{l}\text { Electronic particle } \\
\text { ctr. measurement }\end{array}$} & \multirow[b]{2}{*}{$\alpha$ total } & \multicolumn{4}{|c|}{ - Videographic measurement - } & \multirow[b]{2}{*}{$\mathrm{p}$} \\
\hline & $\alpha$ & $\mathrm{n}$ & & $\mathrm{R}^{2}$ & $\mathrm{n}$ & $\alpha 10 \mathrm{~min}$ & $\mathrm{R}^{2}$ & \\
\hline $12 / 04$ & 0.111 & 6 & -0.0059 & NS & 41 & 0.00039 & NS & $>0.05$ \\
\hline $12 / 06$ & -0.047 & 6 & 0.0032 & NS & 55 & 0.00080 & NS & $>0.05$ \\
\hline $12 / 08 a$ & -0.0076 & 6 & -0.0015 & NS & 32 & 0.00542 & NS & $>0.05$ \\
\hline $12 / 08 b$ & -0.1034 & 6 & -0.0014 & 0.233 & 48 & -0.0129 & 0.378 & $<0.001$ \\
\hline $12 / 10 \mathrm{a}$ & -0.153 & 6 & -0.00046 & NS & 41 & 0.00096 & NS & $>0.05$ \\
\hline $12 / 10 \mathrm{~b}$ & -0.288 & 6 & 0.0016 & 0.141 & 48 & 0.0227 & 0.755 & $<0.01$ \\
\hline $12 / 12 \mathrm{a}$ & 0.008 & 6 & 0.0036 & 0.399 & 42 & 0.0285 & 0.885 & $<0.05$ \\
\hline $12 / 12 b$ & -0.011 & 5 & 0.0085 & 0.578 & 51 & 0.0059 & 0.385 & $<0.0001$ \\
\hline $12 / 14 \mathrm{a}$ & -0.176 & 6 & -0.0012 & 0.128 & 47 & 0.0095 & 0.585 & $<0.01$ \\
\hline $12 / 14 b$ & -0.131 & 6 & 0.0026 & 0.332 & 69 & 0.0276 & 0.743 & $<0.001$ \\
\hline $12 / 16 \mathrm{a}$ & -0.175 & 5 & 0.0036 & 0.596 & 45 & 0.0162 & 0.764 & $<0.02$ \\
\hline $12 / 16 b$ & -0.039 & 6 & 0.0018 & 0.132 & 50 & 0.0118 & 0.402 & $<0.05$ \\
\hline
\end{tabular}


1993). This is also the period in which we are most likely to measure the aggregation of singlets to doublets (see 12/16a data in Fig 4). Nearest neighbor distance calculations (NNDs) allowed us to assess whether the experiments we ran actually conformed to the assumption that singlets are colliding to form doublets. In the Expt 12/16a for example, the proportion of total cells in aggregates (defined as NND $<30 \mu \mathrm{m}$ ) increased from about $5 \%$ at the beginning of the experiment to about $10 \%$ at $10 \mathrm{~min}$ into the experiment. After about 10 min into the experiment, mean particle size is higher than would be possible if only doublets were present. Plotting several points from Expt 12/16a on Fig. 4 suggests that aggregates in this culture actually contained groups of 3 to 10 cells after 10 min, meaning that they do not satisfy the assumptions of the stickiness equation after the first 10 min of rotation within the flocculator.

Furthermore, when in stationary phase (Days 8 to 12 $12 / 12$ to $12 / 16$ ), equivalent spherical diameter often increased rapidly over the first 10 min after which the increase continued at a slower rate (Fig. 5). For this reason we have indicated 2 slopes, the $10 \mathrm{~min}$ initial slope, and the slope over the whole time period. In some cases where the data showed an inflection point, the 10 min slope had a much higher $\mathrm{R}^{2}$ value than the total regression (dashed lines, Fig. 5). For these reasons, we conclude that the first 10 min of flocculator experiments probably do generate the best data for stickiness estimates. Of the 8 significant relationships we generated, 7 slopes showed a higher $\mathrm{R}^{2}$ value for the 10 min slope, mostly by 2 - to 3 -fold (Table 1 ).

This slowing of the aggregation rate over time may be of interest also in that large aggregates dominate late in the experiments (e.g. Fig. 2B), and the dynamics of larger aggregates are very different to that of single

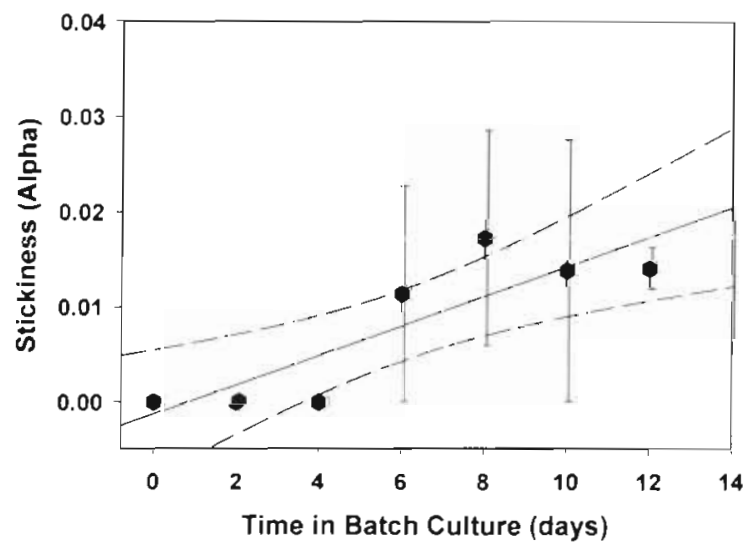

Fig. 6. Chaetoceras neogracile. Mean stickiness coefficient, $\alpha$, plotted against time in batch culture as growth rate slowed due to Si limitation. Error bars represent \pm SD of 2 replicate 12 l cultures. Significant regression line $(p<0.05)$ is shown, with dashed $95 \%$ confidence intervals cells (Jackson \& Lochmann 1993, Johnson et al. 1996). We speculate that we are actually seeing the emergence of another population of larger porous particles in the latter part of the time series, which behaves differently to the original population.

Calculated stickiness $(\alpha)$ was zero at the beginning of the experiment (12/4) since there was no statistically significant slope in the regression of size versus time ( $p>0.05$; Table 1, Fig. 5). Stickiness increased generally over time in batch culture although there was substantial variability (Fig. 6). This result differs from the results generated using the particle counting method, which indicated no measurable stickiness in the same experiments (Table 1). Stickiness also covaried both with cell-surface sugar accumulation as measured in the same cultures using lectin binding, and with the accumulation of transparent exopolymer particles (TEP) in the medium of the cultures (Waite et al. 1995).

Increases in stickiness over time in batch culture, if they reflect real changes in diatom populations that occur in the field, have significant implications for the dynamics of diatom blooms. Model results suggest that an increase in stickiness can accelerate bloom sedimentation via aggregate formation (Jackson \& Lochmann 1992, 1993), which can in turn increase vertical carbon fluxes (Alldredge \& Gotschalk 1989) and cause changes in ecosystem structure in highly productive ecosystems (Hansen et al. 1995). Sudden inputs of carbon to the sea floor can also cause significant and rapid changes in benthic communities (Blair et al. 1996. Goedkoop \& Johnson 1996). Preliminary field work suggests we will be able to determine the extent to which patterns seen in the lab are actually reflected in the field.

The videos taken in the field indicated that the imaging system could easily resolve chains of diatom cells, as well as individual diatom cells within the chains (Fig 7). The images were clear enough to identify the genus and in some cases the species of diatom present. However, because the particle size of interest in the field populations was substantially larger than the solitary species we tested in the laboratory, the small FOV occasionally did not encompass an entire aggregated particle. A larger FOV in which video fields were roughly $10 \times 14 \mathrm{~mm}$, and could encompass entire aggregates of Chatocreas neogracile, formed in the flocculator (Fig. 8).

One of the most interesting observations we made was the appearance of both ball-type aggregates and net-like aggregates in the same cultures. In fact it was difficult to predict which sort of aggregate would be the primary form, though preliminary observations suggest that in cultures that have been grown to extremely high cell densities, ball-like aggregates predominate. One hypothesis might be that the long 


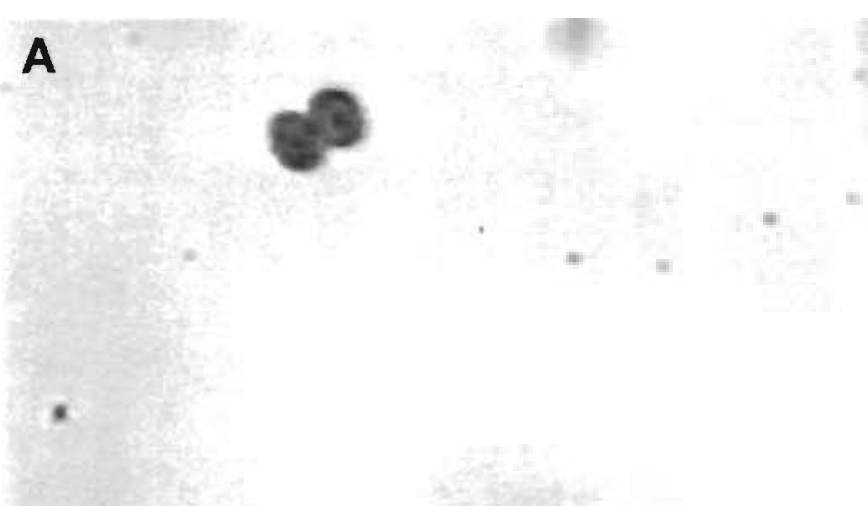

\section{DD:GD: 12: बB}

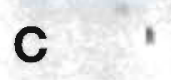

E

\section{DQ: DV: 13:10}

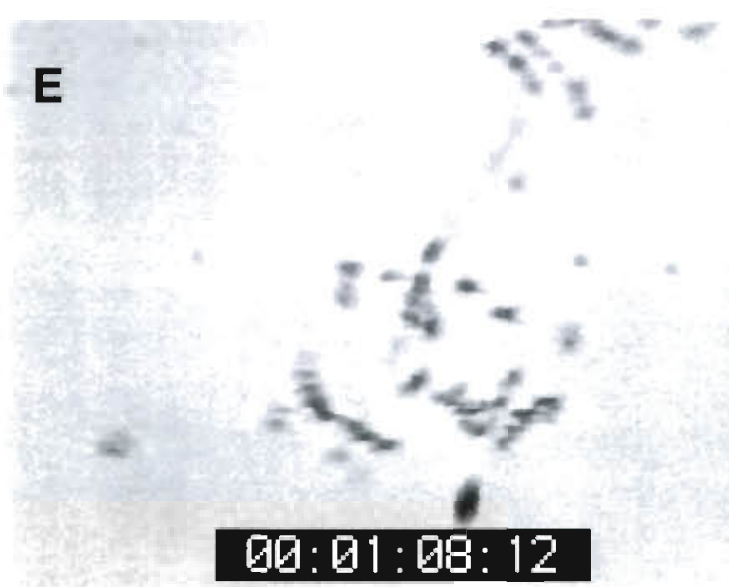

B

\section{G0: 00: 10:15}

D

\section{미: 미:33:14}

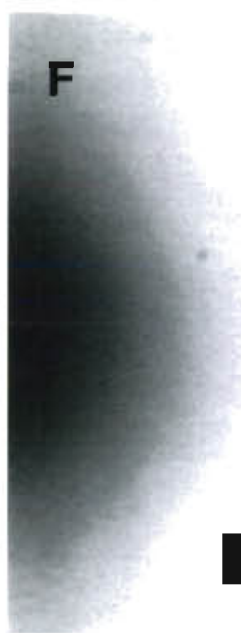

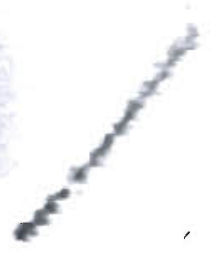

\section{$\square \square: \square 1: 27: 10$}

Fig. 7. Images of field populations suspended in the flocculator made with high resolution video (field of view is $800 \times 400 \mu \mathrm{m}$ ) (A) Two adhering cells of Thalassiosira sp. (B) Chain of 4 cells of Thalassiosira anguste-lineata. (C) Chain of Asterionella glacialis. (D) Cell of medium-sized Chaetoceros sp. (diam. ca $12.5 \mu \mathrm{m}$ ) with 3 adhering cells of smaller Chaetoceros socialis (6 $\mu$ m).

(E) Large cluster of C. socialis. (F) Chain of many cells of Chaetoceros compressum. Note distınctive terminal spines. In all images, particles outside of the plane of focus (ca $20 \mu \mathrm{m}$ in depth) appear fuzzy or indistinct 


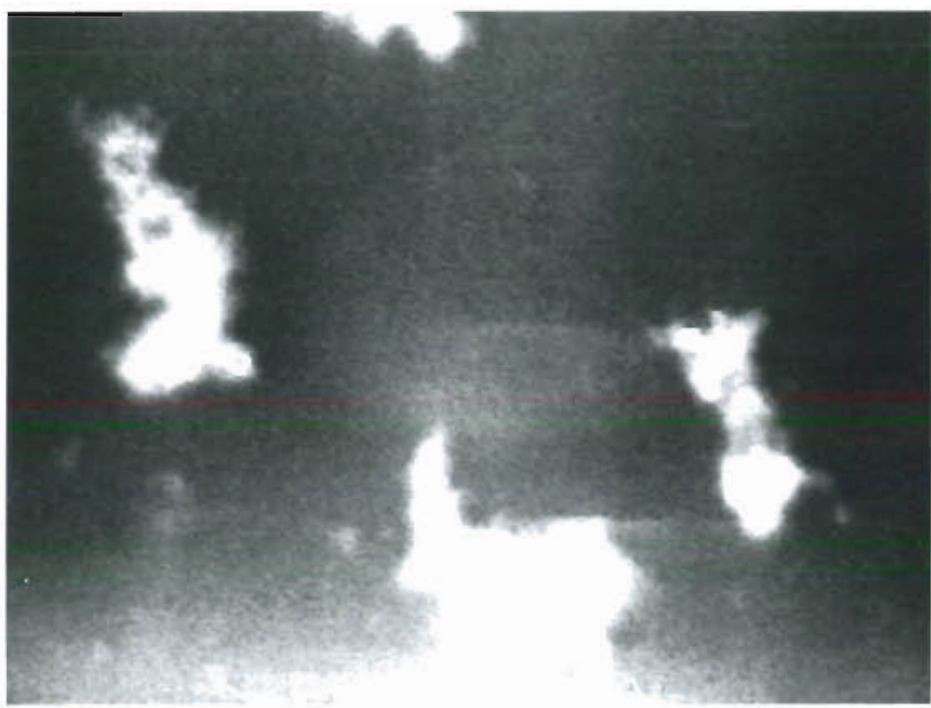

Fig. 8. Chaetoceros neogracile. Low-resolution video image of large ( 1 to $2 \mathrm{~mm}^{2}$ ) aggregates formed in a laboratory flocculator The video field is $14 \times 19 \mathrm{~mm}$. This scale is more appropriate for field measurements where larger particle sizes (e.g. chan-forming bloom diatoms) dominate features will therefore be important in understanding the processes controlling carbon fluxes, especially in ecosystems where sedimentation rates are driven largely by aggregation (Riebesell 1989, 1991, Alldredge et al 1995).

Unlike the results found in dense mesocosm and culture experiments (Smith et al. 1992, 1995), scanning electron micrography (SEM) of our log phase cultures of Chaetoceros neogracile indicates there was very little bacterial colonization of cell surfaces, though there was the occasional bacterium on cell spines (Fig. 3) This was obvious from SEMs even though bacteria would have been concentrated 10 - to 100 -fold on the filters. The potential role of bacteria in modification of diatom adhesion (especially in ball-shaped aggregates) must still be considered uncertain. Especially in nature, where cell concentrations are orders of magnitude lower than in culture experiments, the role of bacteria is still highly debatable. spines of $C$. neogracile break off, or spine formation is incomplete, and cell adhesion thus occurs directly between individual cell surfaces. The extreme regularity of the spacing between cells (e.g. Fig. 2) seems to suggest the presence of spines between them. Another possibility is that TEP accumulating in the medium tend to adhere to cell surface and act to separate the cells. More likely perhaps is a combination of both the latter mechanisms, since TEP concentration increases over time in batch culture, while the dominance of netlike aggregates occurs in more dilute cultures. This suggests that cell morphology might be extremely important in determining aggregate structure.

It is likely that spine formation, cell-surface bound sugars, and TEP all played a role in determining aggregate structure, with surface sugars and TEP the most likely candidates driving stickiness changes in these experiments. All these features can hinge on the bio$\log _{y}$ of the cell Recent work further suggests that cell adhesion can be mediated even more directly by the cell, via enzyme production (Waite et al. 1997) It will therefore be important to consider the physiological features of cells within aggregates when assessing the relationships between particle mass and particle size for the approximation and prediction of particle size spectra (Jackson et al. 1995, Jonasz \& Fournier 1996).

These results also have implications for the prediction of sedimentation rates. It is clear that knowledge of aggregate structure can be critical in estimating settling rates of porous aggregates (Johnson et al. 1996. Li \& Logan 1997). Good measurements of such

\section{CONCLUSIONS}

The addition of videographic particle sizing and particle structure observations to flocculator experiments has increased our temporal resolution in the experiments, and yielded measurements of diatom stickiness we believe are superior to previous estimates, because they are made non-invasively while the experiment is ongoing. Videographic measurements also record a suite of ancillary data of interest to those studying particle dynamics, including individual cell morphology, aggregate structure and porosity, and the movement of particles within an imposed shear. We suggest that biological features such as cell spines and cellsurface sugar accumulation may have a significant impact on aggregate structure, and hence on aggregate dynamics and fluxes. The small field of view (FOV) of our system can resolve individual cells less than $5 \mu m$ in diameter, ideal for detailed measurements on laboratory cultures of solitary phytoplankton species in this lower size range. Larger FOV systems will be more suitable to the coastal ocean blooms where mean particle size is substantially larger

Acknowledgements. A.W was supported by a Woods Hole Oceanographic Scholarship and a Fellowship from the Natural Sciences and Engineering Research Councll of Candad. Initial tests of the video-flocculator system were sponsored by NOAA National Sea Grant College Program Office, Department of Commerce, grant NA90-AA-D-SG480 to A.W. and S.G., Woods Hole Oceanographic Institution Sea Grant Pro- 
ject R/B-129-PD. The views expressed herem are those of the authors and do not necessarly reflect the views of NOAA or any of its subagencies. The Chaetoceros neogracle cultures were provided from the Milford Collection, NMFS, Milford CT, USA. C neogracile experiments in the laboratory of H.D were supported by ONR contract \# N000 14-93-1-022. We thank $R$. Olson for initially suggesting the addition of videographic measurements to the flocculator work. Scanning Electron Microscopy was completed at the Marine Biological Laboratory (MBL) under the Bernard Davis fellowship (to A.W.). Thanks to L. Kerr (MBL) for training and assistance Many thanks to $M$. Walkington for inspired assistance with MATLAB programming. J Mclntosh and S. McClatchie provided useful discussions and comments on the manuscript. T Kiorboe provided A.W. with the unpublished calculations of K. P. Andersen.

\section{LITERATURE CITED}

Alldredge AL, Gotschalk CC (1989) Direct observations of the mass flocculation of diatom blooms: characteristics, settling velocities and formation of diatom aggregates. Deep Sea Res 36:159-171

Alldredge AL, Gotschalk C, Passow U, Riebesell U (1995) Mass aggregation of diatom blooms: insights from a mesocosm study. Deep Sea Res II 42:9-27

Alldredge AL, McGillivary P (1991) The attachment probabilities of marne snow and their implications for particle coagulation in the ocean. Deep Sea Res 38:159-171

Blair NE, Levin LA, DeMaster DJ, Plaia G (1996) The shortterm fate of fresh algal carbon in continental slope sediments. Limnol Oceanogr 41:1208-1219

Burrell DC (1988) Carbon flow in fjords. Oceanogr Mar Biol Annu Rev 26:143-226

Dam HG, Drapeau DT (1995) Coagulation efficiency, organic matter glues and the dynamics of particles during a phytoplankton bloom in a mesocosm study. Deep Sea Res 42: $111-123$

Davis CS, Gallager SM, Solow AR (1992) Microaggregations of oceanic plankton observed by towed video microscopy. Science 257:230-232

Drapeau DT, Dam HG. Greiner G (1994) An improved flocculator design for use in particle aggregation experiments. Lımnol Oceanogr 39:723-729

Gallager SM, Davis CS, Epstein AW, Solow A, Beardsley RC (1996) High-resolution observations of plankton spatial distributions correlated with hydrography in the Great South Channel, Georges Bank. Deep Sea Res Il 43:1627-1663

Gallager SM, Waterbury JB, Stoecker DK (1994) Efficient grazing and utilization of the marine cyanobacterzum Synechococcus sp. by larvae of the bivalve Mercenaria mercenaria. Mar Biol 1 19:251-259

Goedkoop W, Johnson RK (1996) Pelagic-benthic couplıng: profound benthic communty response to spring diatom deposition in mesotrophic lake Erken. Limnol Oceanogr 41:636-647

Hansen JLS, Timm U, Kiorboe T (1995) Adaptive significance of phytoplankton stickıness with emphasis on the diatom Skeletonema costatum. Mar Biol 123:667-676

Hart M (1991) Particle capture and the method of suspension feeding by echinoderm larvae. Biol Bull (Woods Hole) 180:12-27

Jackson GA (1990) A model of the formation of marine algal flocs by physical coagulation processes. Deep Sea Res 37: $1197-1211$

Jackson GA, Lochmann S (1992) Effect of coagulation on nutrient and light limitation of an algal bloom. Limnol Oceanogr 37:77-89

Jackson GA, Lochmann S (1993) Modelling codgulation of algae in marine ecosystems. In: Baffle J, van Leeuwen HP (eds) Environmental partıcles, Vol 2. Lewis Publishers, Boca Raton, p 387-414

Jackson GA, Logan BE, Alldredge AL, Dam HG (1995) Combining particle size spectra from a mesocosm experiment measured using photographic and aperture impedance (Coulter and Elzone) techniques. Deep Sea Res Il 42:139-147

Johnson CP, Li X, Logan BE (1996) Settling velocities of fractal aggregates. Environ SCI Technol 30:1911-1918

Jonasz M, Fourner G (1996) Approximation of the size distrubution of marine particles by a sum of log-normal functuons. Limnol Oceanogr 41:744-754

Kiorboe T, Andersen KP, Dam HG (1990) Coagulation eff1ciency and aggregate formation in marine phytoplankton. Mar Biol 107:235-245

Kiørboe T, Hansen JLS (1993) Phytoplankton aggregate formation: observation of patterns and mechanisms of cell sticking and the significance of exopolymeric materiai. J Plankton Res 15:993-1018

Kıørboe T, Hansen J, Alldredge AL, Jackson GA, Passow U, Dam H. Drapeau D. Waite A, Garcla C (1996) Sedımentation of phytoplankton during a spring diatom bloom: rates and mechanisms. J Mar Res 54:1123-1148

Laws EA, Bienfang PK, Ziemann DA, Conquest LD (1988) Phytoplankton population dynamics and the fate of production during the spring bloom in Auke Bay, Alaska. Limnol Oceanogr 33:57-65

Li XY, Logan BE (1997) Collision frequencies of fractal aggregates with small particles by differential sedimentation. Environ Sci Technol 31:1229-1236

Morel A, Bricaud A (1986) Inherant properties of algal cells including picoplankton: theoretical and experimental results. In: Platt $\mathrm{T}$, Li WKW (eds) Photosynthetic picoplankton. Can Bull Fish Aquat Sci 214

O'Melia CR, Tiller CL (1993) Physicochemical aggregation and deposition in aquatic environments. In: Buffle $\mathrm{J}$, Leeuwen HP Van (eds) Environmental particles. Lewis Publishers, Boca Raton, p 353-386

Riebesell U (1989) Comparison of sinking and sedimentation rate measurements in a diatom winter/spring bloom. Mar Ecol Prog Ser 54:109-119

Riebesell U (1991) Particle aggregatıon dunng a diatom bloom II. Biological aspects. Mar Ecol Prog Ser 69:281-291

Rubenstein DI, Koeh] MAR (1977) The mechanisms of filteI feeding: some theoretical considerations. Am Nat 111. 981-994

Shimeta J, Jumars PA (1991) Physıcal mechanisms and rates of particle capture by suspension feeders. Oceanogr Mar Biol Annu Rev 29:191-257

Smith DC, Simon M, Alldredge AL, Azam F (1992) Intense hydrolytic enzyme activity on marine aggregates and implications for rapid particle dissolution. Nature 359:139-142

Smith DC, Steward GF, Long RA, Azam F (1995) Bacterial mediation of carbon fluxes during a diatom bloom in a mesocosm. Deep Sea Res II 42:75-97

Stoecker DK, Guillard RRL, Kavee RMI (1981) Selective predation by Favella ehrenbergii (Tintinnia) on and among dinoflagellates. Biol Bull (Woods Hole) 160:136-1.45

Straley SC, Bruce VG (1979) Stickiness to glass; circadian changes in the cell surface of Chlamydomonas reinhardi. Plant Physiol 63:1175-1181

Stratford M (1992) Yeast flocculation: a new perspective. Adv Microb Physiol 33:1-71 
van Duuren FA (1968) Defined velocity gradient model flocculator. J Sanit Eng Div Proc Am Soc Civ Eng 94(SA4):671-682

Waite A, Gordon ME, Vreeland V (1997) Enzyme mediated adhesion and cell-surface sugar localization in marine diatoms. Abstract, ASLO Aquatic Sciences Mtgr, Santa Fe,

This article was submitted to the editor
Feb 1997. American Society of Limnology and Oceanography, Waco. TX

Waite A, Olson RJ, Dam HG, Passow U (1995) Measuring sugars on the surfaces of marine diatoms using Concanavalin A and flow cytometry. J Phycol 31:925-933

Manuscnpt received: January 30, 1997 Revised version accepted: June 2, 1997 